\title{
Natural killer cells as helper cells in dendritic cell cancer vaccines
}

\section{María Betina Pampena and Estrella Mariel Levy*}

Centro de Investigaciones Oncológicas CIO-FUCA, Buenos Aires, Argentina

\section{Edited by:}

Nurit Hollander, Tel Aviv University, Israel

\section{Reviewed by:}

Norberto Walter Zwirner, Institute of Biology and Experimental Medicine (IBYME-CONICET), Argentina

Guido Ferlazzo, University of

Messina, Italy

\section{*Correspondence:}

Estrella Mariel Levy, Centro de

Investigaciones Oncológicas

CIO-FUCA, Crámer 1180, Buenos

Aires 1426, Argentina

e-mail: estrellamlevy@yahoo.com.ar
Vaccine-based cancer immunotherapy has generated highly variable clinical results due to differing methods of vaccine preparation and variation in patient populations among other lesser factors. Moreover, these clinical responses do not necessarily correspond with the induction of tumor-specific cytotoxic lymphocytes. Here, we review the participation of natural killer (NK) cells as alternative immune components that could cooperate in successful vaccination treatment. NK cells have been described as helper cells in dendritic cell-based cancer vaccines, but the role in other kinds of vaccination strategies (whole cells, peptide, or DNA-based vaccines) is poorly understood. In this article, we address the following issues regarding the role of NK cells in cancer vaccines: NK cell anti-tumor action sites, and the loci of NK cell interaction with other immune cells; descriptions of new data on the memory characteristics of NK cells described in infectious diseases; and finally phenotypical and functional changes after vaccination measured by immunomonitoring in preclinical and clinical settings.

Keywords: cancer vaccines, natural killer cells, immunomonitoring, dendritic cells vaccines, NK cells-dendritic cells crosstalk

\section{INTRODUCTION}

Within the lymphocyte gate in the flow cytometric analyzer, natural killer (NK) cells are usually defined as $\mathrm{CD}^{-}$(thereby excluding $\mathrm{T}$ cells) and $\mathrm{CD} 56^{+}$, an isoform of the neural cell adhesion molecule (NCAM) (1). NK cells constitute about $5-20 \%$ of peripheral blood $(\mathrm{PB})$ mononuclear cells and are also found in many tissues such as the liver, peritoneal cavity, placenta, uterine mucosa, and lungs (2-6). Approximately, $90 \%$ of $\mathrm{PB}$ and spleen NK cells are CD56 ${ }^{\mathrm{dim}} \mathrm{CD} 16^{+}$and are characterized by a potent cytotoxic activity after interaction with target cells. On the other hand, NK cells in lymph nodes and tonsils are mostly $\mathrm{CD} 56^{\text {bright }} \mathrm{CD} 16^{\mathrm{dim} /-}$ and have a helper role in the production of IFN- $\gamma$ in response to IL-12, IL-15, IL-18, and type I IFN stimulation $(1,6,7)$. Unlike T and B cells, NK cells have the unique ability to kill transformed or virally infected cells without prior sensitization. Furthermore, NK cells are rapidly recruited to the sites of virus entry and are critical for the control of acute viral infections $(8,9)$. In fact, individuals with NK cell deficiency suffer recurrent viral infection as a result of their impaired ability to develop lasting and effective antigen $(\mathrm{Ag})$-specific recall responses $(8,9)$. Moreover, NK cells can eliminate tumor cells, as has been shown both in vivo and in vitro $(10,11)$. NK cells spare healthy cells that express MHC class I molecules and low levels of stress-induced self-molecules, but are capable of recognizing and directly killing a wide variety of tumor or virally infected cells with reduced levels of MHC class I molecules or that overexpress stress-induced activating cell surface molecules (e.g., MICA/B recognition via NKG2D) that may otherwise escape immune detection. These are known as the "missing-self" and "non-self" phenomenon, respectively (12). Additionally, NK cells are involved in the immune response against tumor metastasis (13). For instance, in a mouse model of metastatic lung cancer, authors found that NK cells prevented pulmonary metastasis and peritoneal dissemination following treatment with cationic liposomes complexes formed by CpG DNA (14). Another mouse model of lung metastases showed that NK cell depletion abolished the protective effect of IFN- $\gamma$ treatment on metastases. In fact, there was crosstalk between NK cells and tumor cells through the IFN- $\gamma$-induced transcription factor IRF1 , which is expressed on tumor cells, supporting the pulmonary attraction and activation of NK cells (15). Direct tumor cell lysis by NK cells is thought to be mediated principally by perforins, as shown in vivo using experimental models of metastases in mice $(16,17)$. However, NK subset depletion resulted in more instances of metastases than observed in perforin-deficient mice, suggesting that the perforin-independent effector functions of NK cells may also contribute to protection from tumor metastasis. Moreover, NK cells can also induce tumor cell elimination through death receptor-mediated pathways such as TRAIL and FasL (18-20). On the other hand, activated NK cells are also potent producers of numerous immunomodulatory cytokines, including IFN- $\gamma$, TNF$\alpha$, growth factors such as G-CSF and GM-CSF, and numerous chemokines (21).

In humans, NK cells play an important role in tumor immunosurveillance alongside specific $\mathrm{T}$ lymphocytes. In an 11-year follow-up survey of a Japanese cohort study, it has been shown that low peripheral NK cell activity is associated with increased cancer risk (22). Other clinical studies have provided evidence that in several different solid tumors, such as lung, gastric, colorectal, and head and neck cancers, the presence of high numbers of tumorinfiltrating NK cells correlates with improved prognosis of cancer patients (pts) $(23,24)$. Moreover, decreased NK cell activity was observed in pts with hereditary colorectal adenocarcinoma (25, 
26); and melanoma pts with metastatic disease have an impaired perforin-dependent NK cell cytotoxic mechanism (27). Menard et al. demonstrated the relevance of NK cells in gastrointestinal stromal tumor-bearing pts treated with imatinib mesylate (a tyrosine-kinase inhibitor). Apparently, those patients whose NK cell IFN- $\gamma$ values were higher than or equal to their trialentry baseline value after 2 months of therapy had prolonged disease-free survival compared to the others pts (28).

Considering the important role that NK cells have an immunosurveillance, it is desirable to focus the development of cancer therapies to augment NK cell killing and helping efficacy because it could aid in the induction of an optimal adaptive immune response against cancer.

\section{NK CELL LOCALIZATION, TRAFFICKING, AND THE NK CELL DETECTION ISSUE}

Even though NK cells seem to be critical immune effectors in tumor cell elimination in in vitro experiments and animal models, they have a limited capacity to traffic to tumor sites. Of note, in humans, factors regulating NK cell recruitment into neoplastic tissues are highly influenced by the tumor type and by the chemokine profile of the tumor microenvironment. A recent study suggested that $\mathrm{CD}^{2} 6^{+} \mathrm{NK}$ cells could scarcely infiltrate melanomas, hepatocellular carcinomas, breast cancers, and renal cell carcinomas (29). Other studies reported that in solid tumors, NK cells are often located within the stroma area, not in direct contact with tumor cells, and are usually functionally anergic $(30,31)$. However, in this setting, it is difficult to establish whether these NK cells are activated (high CD56) NK cells that lost perforin expression through degranulation, or if they constitute an altered NK cell phenotype induced by the tumor cells.

A more recent study found that NK cells were widely distributed in most solid normal and neoplastic tissues and that the relative proportion of NK subsets infiltrating was different upon malignant transformation, with a trend toward a tumor-infiltrating NK population enriched in non-cytotoxic cells (6). Moreover, NK cells from melanoma metastatic lymph nodes were found surrounding tumor cell clusters and although they were mostly CD56 ${ }^{\text {bright }}$ and inactive, they could be activated ex vivo by IL-2 or IL-15 and could lyse metastatic melanoma cells more efficiently than bloodderived NK cells (32). The appropriate activation of this NK cell subset could unfold their helper function, thereby turning $\mathrm{T}$ cell activation toward a $\mathrm{TH}_{1}$ response.

However, the apparent limited capacity of NK cell trafficking to tumor sites could be an artifact of the NK cell detection techniques used. NK cell detection methods are still a source of discussion because of doubts about the accuracy of the antibodies and molecular targets used in NK cell tissue-associated detection. Of note are the substantial differences when compared with tissue detection of T CD4 and T CD8 cells, which have good and reliable antibodies for immunohistochemistry.

As illustrated in Table 1, NK cell detection depends on the technique and molecular target used. There are several papers showing that NKp46 presents important advantages over other NK cell markers, such as CD56 or CD57, in the identification

Table 1 | Detection of NK cells in different normal or neoplastic tissues by technique and molecular target.

\begin{tabular}{|c|c|c|c|c|}
\hline Method/technique & Target molecule & $\begin{array}{l}\text { NK cell } \\
\text { presence }\end{array}$ & $\begin{array}{l}\text { Human normal or } \\
\text { neoplastic tissue }\end{array}$ & Reference \\
\hline \multirow[t]{12}{*}{ Immunohistochemistry } & CD57 (c NK-1) & Yes & Squamous cell lung cancer & (24) \\
\hline & CD56 (c 123C3) & No or almost & Melanoma & $(29,33)$ \\
\hline & & undetectable & Hepatocellular carcinoma & \\
\hline & & & Breast cancer & \\
\hline & & & Renal cell carcinoma & (34) \\
\hline & CD56 (c 123C3) & Yes & Breast cancer & $(35)$ \\
\hline & CD56 (ns) & Yes & Melanoma & $(36)$ \\
\hline & CD57 (c NC1) & Yes & Gastric cancer & $(37)$ \\
\hline & NKp46 (c 195314) & Scarce & Colorectal cancer & $(30)$ \\
\hline & & Yes & Lung, breast and colon (normal and tumor tissue) & $(6)$ \\
\hline & & & Metastatic melanoma lymph nodes & $(32)$ \\
\hline & & & Non-small cell lung cancer & (38) \\
\hline Immunofluorescence & NKp46 (polyclonal), CD56 (c 123C3) & Yes & Spleen, gut and colon & (39) \\
\hline RT-PCR & $\begin{array}{l}\text { Specific differentially methylated } \\
\text { regions near NKp46 gene }\end{array}$ & Yes & $\begin{array}{l}\text { Leukocytes from peripheral blood from head and } \\
\text { neck cancer pts }\end{array}$ & $(40)$ \\
\hline \multirow{4}{*}{$\begin{array}{l}\text { Flow cytometry (from } \\
\text { disaggregated tissue) }\end{array}$} & CD56 (c AF12-7H3), NKp46 (с 9E2) & Yes & Lung, breast and colon (normal and tumor tissue) & (31) \\
\hline & & & Gut and colon tissue & (39) \\
\hline & & & Colorectal cancer & $(41)$ \\
\hline & & & Breast cancer & $(42)$ \\
\hline
\end{tabular}

c, clone; ns, not specified. 
of human NK cells by immunohistochemistry. Moreover, NKp46 is commonly used for NK cell detection by flow cytometry and RT-PCR.

\section{NK-DENDRITIC CELL CROSSTALK}

Altogether, it is well accepted that NK cells possess potent antitumor functions that could be targeted for immune-based therapies (43-46). NK cell direct killing of target cells also impacts $\mathrm{T}$ cell responses, possibly by decreasing the antigenic load (47) and because target cell debris may promote Ag cross-presentation to $\mathrm{CD}^{+}$cytotoxic T cells (48). However, these direct anti-tumor effects can be attributed not only to cytotoxicity but also to their cytokine-producing capacities (IFN- $\gamma$, TNF- $\alpha$, IL-10). Because NK cells can also indirectly contribute to tumor control by communicating with other immune cells (e.g., dendritic cells - DCs, NKT cells, macrophages, and T cells), there is an efficient adaptive antitumor response $(12,21,49)$. Furthermore, it is well known from in vitro studies and colocalization experiments that NK cells can interact bidirectionally with DCs in areas of inflammation causing DC maturation, a consequent enhancement of NK cell function through positive feedback and exerting an influence on the polarization of primary $\mathrm{T}$ cell-responses toward a $\mathrm{TH}_{1}$ response (50-55). In fact, mature DCs can activate NK cell cytotoxicity and IFN- $\gamma$ production, whereas activated NK cells are capable of enhancing DC maturation and IL-12 production. The previously described interactions are cell contact and TNF- $\alpha$-dependent (50, 56-58). Furthermore, mature DCs recruit NK cells to the lymph nodes, where NK cells serve as an early source of the IFN- $\gamma$ necessary for $\mathrm{TH}_{1}$ polarization, possibly by direct interaction with naïve T cells (54).

On the other hand, it has been shown that activated NK cells can kill autologous immature DCs, while they spare fully activated DCs. This work lead to the proposal that activated NK cells might select a more immunogenic subset of DCs during a protective immune response $(58,59)$. Interestingly, in a recent mouse model of vaccination against breast cancer, authors showed that the addition of YAC-1 (a NK target cell devoid of MHC) in a vaccine composed of irradiated tumor cells boosted the expansion of tumor-specific cytotoxic T lymphocytes, eventually resulting in enhanced survival of mice upon challenge with a lethal dose of tumor cells. NK cells removed immature tolerogenic DCs and the residual DCs were highly immunogenic. These DCs could induce proper $\mathrm{T}$ cell clonal expansion, which gave anti-tumor protection. The depletion of NK cells impaired the tumor-specific $\mathrm{T}$ cell response and, consequently, their protective roles upon tumor challenge (60). In a more recent tumor model, Bouwer et al. found that in vivo depletion of NK cells at the time of tumor challenge completely abolished the benefit of bacteria-stimulated DC immunotherapy. Although $\mathrm{CD}^{+}$or $\mathrm{CD}^{+} \mathrm{T}$ cells may be required for an optimal anti-tumor response, the loss of NK cells resulted in a more profound defect in tumor immunity. They also found that NK cells exert a helper role in priming and reactivating tumor-specific $\mathrm{T}$ cells because the contribution of NK cells was dependent on tumor-Ag presentation by DCs. However, unlike the previous work, the contribution of NK cells in the context of this vaccination did not rely on the perforin-dependent lysis of tolerogenic DCs in draining lymph nodes because IFN- $\gamma$, not perforin, was essential for the success of DC immunotherapy (61).

Since NK cells cooperate with DCs and T cells to enhance antitumor responses, cancer vaccines could be improved by strategies aimed at activating NK cells. There is a rationale for NK cell immunomonitoring in cancer immunotherapeutic approaches. However, although it is clear that effector cells are the main targets of immunotherapy, treatments should also focus on immune cell trafficking to tumor sites. The knowledge that tumors disrupt $\mathrm{T}$ and NK cell homing through different mechanisms is useful for the implementation of combination immunotherapies to overcome these immunosuppressive mechanisms (62).

\section{NK CELL MEMORY}

In recent years, a new role for NK cells has been described. Under certain experimental conditions, NK cells share some features with adaptive immune cells, such as the Ag-dependent expansion observed in mice infected with murine cytomegalovirus. This NK cell subset expansion is associated with long-lasting functional changes with features similar to memory $\mathrm{T}$ cell populations (63). There is another mouse model in which the challenge is made by hapten-induced contact hypersensitivity. Work in this model demonstrated that these memory-NK cells are confined to the liver, since hapten-specific memory is conferred to naïve mice by adoptive transfer only of liver NK cells from sensitized donors $(64,65)$. In another work, the authors show that in vitro cytokineactivated NK cells transferred into naïve recipients can persist for at least a month. Although they are phenotypically similar to naïve cells and do not constitutively produce IFN- $\gamma$, these memory-like NK cells produce significantly more IFN- $\gamma$ when restimulated, displaying an intrinsic capacity to respond more robustly after reactivation with cytokines or via engagement of activating $\mathrm{NK}$ receptors (66). However, Horowitz et al. demonstrated in an experimental model of a rabies virus vaccine, that there are no intrinsic differences between prevaccination and post-vaccination NK cells, although the last cells to respond have a more robust response. In fact, post-vaccination NK cells are simply responding to IL-2 produced by memory CD $4{ }^{+} \mathrm{T}$ cells and IL- 12 and IL- 18 produced by accessory cells after virus rechallenge (67).

Nevertheless, there is a lack of definitive evidence for NK cell memory in humans. Study suggests that infection with human cytomegalovirus skews the NK cell receptor repertoire toward the activating CD94/NKG2C receptor that is usually expressed on $<10 \%$ of total NK cells in PB (68). After expansion, the $\mathrm{NKG}^{+} \mathrm{C}^{+}$ NK cells were more potent producers of IFN- $\gamma$ than their NKG2C counterparts and expressed CD57, a marker of terminal differentiation (69). These findings suggest that once NK cells are activated, they acquire certain characteristics that influence their behavior during subsequent encounters with Ags.

\section{IMMUNOMONITORING}

The primary objective of immune monitoring in cancer vaccine clinical trials is to find a correlation between an efficient induction of tumor-specific $\mathrm{T}$ cell responses and clinical efficacy that reflects the importance of the host immune system in controlling tumor progression. However, although there is evidence of increased frequency of tumor-specific $\mathrm{T}$ cells in several cancer vaccine trials, 
no validated biomarkers exist yet for cancer immunotherapy. As mentioned above, NK cells cooperate with T cells to enhance antitumor response and this emphasizes the importance of optimizing NK cell activation for tumor immunotherapeutic protocols. NK cell monitoring was studied more frequently in tumor-Ag-loaded DC immunization trials (Table 2). The range of vaccines developed has included peptide/protein-based vaccines, cell lysates, and whole-tumor cell vaccines with different delivery systems and adjuvants (70). In practice, though, only a few groups have implemented the evaluation of NK cells in clinical trials. Table 2 provides an overview of DC-based tumor vaccination trials implementing NK cell monitoring. The main NK cell activities include IFN$\gamma$ production and lytic activity against the K562 cell line. High IFN- $\gamma$ production is an indicator of resident immunostimulatory NK cells, which is especially interesting in light of DC-based approaches. Other cytokines produced by NK cells, e.g., TNF- $\alpha$, GM-CSF, IL-10, and IL-13, may be considered for the evaluation of tumor cell sensitivity to NK cell-mediated killing and could be significant predictive markers for therapy effectiveness (71). Moreover, NK cells are defined by their intrinsic capacity to kill transformed cells and in this sense, their activation could be evaluated as the capacity to degranulate, produce granzymes or perforins, and lyse tumor target cells or their canonical target, the K562 cell line. However, it is important to note that cytotoxicity against the universal target K562 may not correlate to cytotoxicity against patient tumor cells.

Natural killer cell immunomonitoring in DC vaccine clinical trials showed a correlation between the clinical responses of treated pts and NK cell status. NK cell responses were analyzed in a phase I trial of a vaccine consisting of autologous DCs loaded with a fowlpox vector encoding CEA and the data were compared with pt clinical outcome. DCs enhanced NK activity in vitro, by both sustaining NK cell survival and by enhancing the expression of NK-activating receptors, including NKp46 and NKG2D. Of the nine pts, four had increased cytolytic NK activity, including three pts with increased NK cell frequency; this remained stable in two pts and decreased in three as compared to pretreatment values. NKp46 and NKG2D expression were correlated with the pts' NK cell activity. When pts were grouped by clinical response, the majority in the stable/NED (no evident disease) group had increased NK activity. Anti-CEA T cell response was enhanced in all of the nine pts analyzed, but it was not significantly different between groups. Thus, NK responses following DC vaccination may correlate more closely with clinical outcome than do $\mathrm{T}$ cell responses (73). In a study of ER/PR double-negative stage II/IIIA breast cancer pts vaccinated with autologous DCs pulsed with autologous tumor lysates, $\mathrm{DC}$ vaccines elicited $\mathrm{TH}_{1}$ cytokine secretion and increased the number of NK cells (78). In another immunization treatment with monocyte-derived DC incubated with preheated autologous tumor lysate and subsequently with IFN- $\gamma$, TNF- $\alpha$, and polyinosinic:polycytidylic acid to attain type 1 maturation, treatment induced sustained, elevated IL-12 serum levels that correlated with the IL-12p70 output of cultured DC from each individual. NK activity in $\mathrm{PB}$ increased and was also correlated with the IL-12p70 serum concentration in each pt (76).

As mentioned above, NK cells were mostly studied in the context of antigen-loaded DC immunotherapy, and so far, we were not able to find another tumor vaccine study highlighting the importance of this lymphocyte subset. In our laboratory, we are testing an anti-melanoma vaccine composed by four irradiated melanoma cell lines plus BCG and GM-CSF as adjuvants against conventional IFN- $\alpha$ therapy. We have not seen changes in T CD4 ${ }^{+}$ or $\mathrm{T} \mathrm{CD}^{+}$cell frequencies post-treatment, although we did find a significant increase in NK cell number and frequency in vaccinated pts when comparing pre- and post-treatment samples. Studies are needed to find the cause of this NK cell number increase, and to see if this effect is correlated with pt clinical outcome (80).

Antibody-dependent cellular cytotoxicity (ADCC) is probably the most thoroughly evaluated activity performed by NK cells during treatment with monoclonal antibodies. NK cells can trigger ADCC to lyse IgG opsonized target cells. Several authors have reported a correlation between NK function and response to treatment with Cetuximab, Rituximab, and Trastuzumab in animal models and cancer pts $(81,82)$. Not only ADCC but also NK-CD interaction was observed in antibody treatments. For example, the interactions between Cetuximab with cancer cell EGFR and NK cell Fc $\delta$ R IIIa enhances cross-presentation of tumor Ags, such as EGFR by DC to cytotoxic T lymphocytes. In fact, there are more circulating EGFR-specific T cells in Cetuximab-treated head and neck cancer pts than in treatment naïve pts (83). This suggests that antibody administration could trigger a tumor-Ag-specific cellular immune response and could be combined with cancer vaccines to improve cancer immunotherapy.

In summary, although immunomonitoring demonstrated NK cell relevance in DC immunotherapeutic approaches and a correlation with pt response in several clinical trials, our understanding of their role remains incomplete. In fact, doubts remain about whether NK cells function primarily through tumor cytotoxicity or if NK cells also exert a relevant helper function through their interaction with DCs, T cells, and other immune cells. This second type of interaction remains the source of much discussion. Consequently, it is important to monitor NK cell numbers as well as phenotypic and functional changes, such as the ability to exert tumor cell lysis and the production of immunomodulatory cytokines during the course of immunotherapy. Furthermore, addressing the capacity of treatment to generate the kind of NK memory-cell described in the prior section (for example, measuring changes on NKG2C expression after treatment) could contribute to the long-term protection expected from cancer vaccines.

\section{CONCLUDING REMARIKS}

This review ventured beyond a description of the plurality of NK cell activities into the changes that therapeutic cancer vaccines can affect in NK cells, and how these lymphocytes can potentiate the immune system through DC vaccination. In this bidirectional crosstalk, NK cells hold the capacity to control and enhance DC-mediated anti-tumor immune responses by inducing the maturation of $\mathrm{TH}_{1}$-polarizing DCs, providing DCs with antigenic material for presentation and by killing inappropriately matured DCs. On the other hand, DCs stimulate NK cells by both soluble and contact-dependent activators, thereby enhancing their cytokine production, proliferation, survival, and cytotoxicity. Although this DC-NK cell interaction has been demonstrated in vitro and in animal models, a review of the literature found very 
Table 2 | NK cell immunomonitoring from different clinical trials using dendritic cell cancer vaccines.

\begin{tabular}{|c|c|c|c|c|c|c|c|}
\hline Protocol & $\begin{array}{l}\text { Vaccine } \\
\text { type }\end{array}$ & $\begin{array}{l}\text { Tumor } \\
\text { type }\end{array}$ & $\begin{array}{l}\text { NK } n^{\circ} \text { and } \\
\text { phenotypic } \\
\text { changes }\end{array}$ & $\begin{array}{l}\text { NK cells } \\
\text { lysis }\end{array}$ & $\begin{array}{l}\text { NK cells } \\
\text { cytokines } \\
\text { production }\end{array}$ & $\begin{array}{l}\text { Association } \\
\text { with pts } \\
\text { outcome }\end{array}$ & $\begin{array}{l}\text { Refer- } \\
\text { ence }\end{array}$ \\
\hline Phase I trial & $\begin{array}{l}\text { Autologous DCs } \\
\text { loaded with a } \\
\text { fowlpox vector } \\
\text { encoding CEA }\end{array}$ & $\begin{array}{l}\text { CRC, lung cancer } \\
\text { and urachal } \\
\text { adenocarcinoma }\end{array}$ & $\begin{array}{l}5 / 9 \text { pts } \uparrow N K \text { cell } n^{\circ} \\
\text { during vaccination, } 2 \text { did } \\
\text { not change and } 2 \downarrow N K \\
\text { cell } n^{\circ} . \downarrow N K G 2 A \text { in } 2 / 5 \\
\text { pts; } \uparrow N K G 2 D \text { in } 3 / 5 \text { pts. } \\
\text { NKp46 and NKG2D } \\
\text { expression correlated } \\
\text { with activity }\end{array}$ & $\begin{array}{l}4 / 9 \text { pts } \uparrow \text { NK cell } \\
\text { activity ( } 3 \text { of } \\
\text { them had also } \\
\uparrow N K \text { cell } \\
\text { numbers). } 2 / 9 \\
\text { stable NK cell } \\
\text { activity, and } 3 / 9 \\
\downarrow N K \text { cell activity }\end{array}$ & $\begin{array}{l}\text { Not } \\
\text { evaluated }\end{array}$ & $\begin{array}{l}4 \text { of } 5 \text { SD/NED pts had } \\
\uparrow N K \text { cell activity }\end{array}$ & (73) \\
\hline Pilot trial & $\begin{array}{l}\text { DCs loaded with } \\
\text { autologous HS- } \\
\text { and } \\
\text { UV-C-treated } \\
\text { tumor cells }\end{array}$ & $\begin{array}{l}\text { FL B cell NHL } \\
\text { and lymphoplas- } \\
\text { mocytoid } \\
\text { lymphoma }\end{array}$ & $\begin{array}{l}\uparrow \mathrm{CD}^{-}{ }^{-} \mathrm{CD} 56^{\mathrm{dim}} \mathrm{CD}^{+} 6^{+} \\
\text {and } \uparrow \mathrm{CD} 16 \mathrm{MFI} \text { ratios } \\
\text { and } \uparrow \mathrm{NKp} 46 \text { after } \\
\text { treatment }\end{array}$ & Not evaluated & $\begin{array}{l}\text { Not } \\
\text { evaluated }\end{array}$ & $\begin{array}{l}\uparrow \mathrm{CD}^{-}{ }^{-} \mathrm{CD} 56^{\mathrm{dim}} \mathrm{CD} 16^{+} \text {in } \\
\mathrm{R} \text { compared with NR pts. } \\
\uparrow \mathrm{NKp} 464 / 6 \mathrm{R} \text { pts in } \\
\text { comparison with } 1 / 4 \mathrm{NR} \\
\text { pts with a similar change }\end{array}$ & (74) \\
\hline $\begin{array}{l}\text { Phase } 1 / \| I \\
\text { trial }\end{array}$ & $\begin{array}{l}\text { Monocyte- } \\
\text { derived WT1 } \\
\text { mRNA-loaded } \\
\text { DC }\end{array}$ & AML & $\begin{array}{l}\uparrow \mathrm{HLADR}^{+} \mathrm{NK} \text { cells in } \\
\text { pts after treatment }\end{array}$ & Not evaluated & $\begin{array}{l}\text { Not } \\
\text { evaluated }\end{array}$ & $\begin{array}{l}\text { Correlation between CR } \\
\text { and } \uparrow \text { of activated NK cells } \\
\text { post-vaccination (i.e., more } \\
\text { than } 40 \% \text { HLA-DR + cells } \\
\text { within the total NK cell } \\
\text { population in } 4 / 5 \mathrm{CR} \text { and } \\
0 / 5 \mathrm{NR} \text { ) }\end{array}$ & (75) \\
\hline $\begin{array}{l}\text { Phase I/II } \\
\text { trial }\end{array}$ & $\begin{array}{l}\text { Autologous } \\
\text { DCs + IL-2 }\end{array}$ & $\begin{array}{l}\text { Renal cell } \\
\text { carcinoma and } \\
\text { BC }\end{array}$ & $\begin{array}{l}2 / 6 \text { pts } \uparrow \\
\text { CD } 16^{+} \text {CD } 56^{\text {dim }}\end{array}$ & $\begin{array}{l}6 / 10 \text { pts } \uparrow \\
\text { cytotoxic activity } \\
\text { vs. K562 cells }\end{array}$ & $\begin{array}{l}\text { Not } \\
\text { evaluated }\end{array}$ & $\begin{array}{l}\text { Only one patient with } \\
\text { objective } \mathrm{CR} \text {, associated } \\
\text { with } \mathrm{CD} 8^{+} \mathrm{IFN} \gamma \text { production }\end{array}$ & (77) \\
\hline Phase I & $\begin{array}{l}\text { DCs loaded with } \\
\text { autologous } \\
\text { tumor lysates }\end{array}$ & $\begin{array}{l}\mathrm{ER}^{-} / \mathrm{PR}^{-} \text {stage } \\
\text { II/IIA BC }\end{array}$ & $\uparrow n^{\circ}$ of NK cells & Not evaluated & $\begin{array}{l}\text { Not } \\
\text { evaluated }\end{array}$ & Not analyzed & (78) \\
\hline Phase I & $\begin{array}{l}\text { DC pulsing with } \\
\text { autologous } \\
\text { tumor cell } \\
\text { lysates }\end{array}$ & $\begin{array}{l}\text { Recurrent } \\
\text { Glioblastoma }\end{array}$ & $\begin{array}{l}6 / 15 \text { pts } \uparrow \% \text { of NK } \\
\text { cells, which further } \\
\text { augmented after the } \\
\text { second vaccination }\end{array}$ & Not evaluated & $\begin{array}{l}\uparrow \mathrm{IFN} \gamma \\
\text { associated } \\
\text { with a } \uparrow \% \text { of } \\
\mathrm{NK} \text { cells after } \\
\text { the first } \\
\text { vaccination }\end{array}$ & $\begin{array}{l}\text { Pts with } \uparrow N K \text { V/B ratio had } \\
\text { longer PFS and OS. And pts } \\
\text { with } \uparrow T G F \beta 2 \text { and VEGF V/B } \\
\text { ratios had a shorter PFS } \\
\text { and OS }\end{array}$ & (79) \\
\hline
\end{tabular}

$n^{\circ}$, numbers; $\uparrow$, increase; $\downarrow$, decrease; CR, clinical responders; FL, follicular; NHL, non-Hodgkin lymphomas; lymphoplasmocytoid lymphoma; $R$, responder; NR, non-responder; IL, interleukin; ITI, intratumoral injection; PR, partial response; SD, stable disease; NED, no evident disease; PFS, progression free survival; OS, overall survival; V/B, vaccination/baseline ratio; CTX, cyclophosphamide; PegIFN, PegIFN alpha-2a; HCC, hepatocellular carcinoma; BC, breast cancer; ChC, cholangiocarcinoma; CRC, colorectal carcinoma; Carc, carcinoid tumor; $M$, melanoma; HS, heat-shocked. 
few clinical trials that performed NK cells immunomonitoring. The majority of these DC cancer vaccine clinical trials showed a correlation between NK cell number/percentage and/or activity augmentation and pt outcome. Surprisingly, to the best of our knowledge, NK cell analysis has not been carried out in trials for other kinds of tumor vaccines. To gain more knowledge about the role of NK cells in immunotherapeutic cancer vaccines, NK cell monitoring must be systematically incorporated into clinical vaccination trials. This could lead to a better understanding of the real impact of NK cells in the vaccine field.

\section{REFERENCES}

1. Caligiuri MA. Human natural killer cells. Blood (2008) 112(3):461-9. doi:10. 1182/blood-2007-09-077438

2. King A, Burrows T, Loke YW. Human uterine natural killer cells. Nat Immun (1996) 15(1):41-52.

3. Luo D, Vermijlen D, Vanderkerken K, Kuppen PJ, Seynaeve C, Eddouks M, et al. Involvement of LFA-1 in hepatic NK cell (pit cell)-mediated cytolysis and apoptosis of colon carcinoma cells. J Hepatol (1999) 31(1):110-6. doi:10.1016/S0168-8278(99)80170-6

4. Robertson MJ, Ritz J. Biology and clinical relevance of human natural killer cells. Blood (1990) 76(12):2421-38.

5. Trinchieri G. Biology of natural killer cells. Adv Immunol (1989) 47:187-376. doi:10.1016/S0065-2776(08)60664-1

6. Carrega P, Bonaccorsi I, Di Carlo E, Morandi B, Paul P, Rizzello V, et al. CD56 (bright)perforin(low) noncytotoxic human NK cells are abundant in both healthy and neoplastic solid tissues and recirculate to secondary lymphoid organs via afferent lymph. J Immunol (2014) 192(8):3805-15. doi:10. 4049/jimmunol.1301889

7. Cooper MA, Fehniger TA, Caligiuri MA. The biology of human natural killer-cell subsets. Trends Immunol (2001) 22(11):633-40. doi:10.1016/S1471-4906(01) 02060-9

8. Herberman RB, Djeu J, Kay HD, Ortaldo JR, Riccardi C, Bonnard GD, et al. Natural killer cells: characteristics and regulation of activity. Immunol Rev (1979) 44:43-70. doi:10.1111/j.1600-065X.1979.tb00267.x

9. Fujimiya Y, Babiuk LA, Rouse BT. Direct lymphocytotoxicity against herpes simplex virus infected cells. Can J Microbiol (1978) 24(9):1076-81. doi:10.1139/ m78-177

10. Lakshmikanth T, Burke S, Hassan TA, Kimpfler S, Ursini F, Ruggeri L, et al. NCRs and DNAM-1 mediate NK cell recognition and lysis of human and mouse melanoma cell lines in vitro and in vivo. J Clin Invest (2009) 119(5):1251-63. doi:10.1172/JCI36022

11. Stagg J, Smyth MJ. NK cell-based cancer immunotherapy. Drug News Perspect (2007) 20(3):155-63. doi:10.1358/dnp.2007.20.3.1092096

12. Vivier E, Tomasello E, Baratin M, Walzer T, Ugolini S. Functions of natural killer cells. Nat Immunol (2008) 9(5):503-10. doi:10.1038/ni1582

13. Dewan MZ, Terunuma H, Takada M, Tanaka Y, Abe H, Sata T, et al. Role of natural killer cells in hormone-independent rapid tumor formation and spontaneous metastasis of breast cancer cells in vivo. Breast Cancer Res Treat (2007) 104(3):267-75. doi:10.1007/s10549-006-9416-4

14. Zhou S, Kawakami S, Higuchi Y, Yamashita F, Hashida M. The involvement of NK cell activation following intranasal administration of CpG DNA lipoplex in the prevention of pulmonary metastasis and peritoneal dissemination in mice. Clin Exp Metastasis (2012) 29(1):63-70. doi:10.1007/s10585-011-9429-1

15. Ksienzyk A, Neumann B, Nandakumar R, Finsterbusch K, Grashoff M, Zawatzky $\mathrm{R}$, et al. IRF-1 expression is essential for natural killer cells to suppress metastasis. Cancer Res (2011) 71(20):6410-8. doi:10.1158/0008-5472.CAN-11- 1565

16. Smyth MJ, Thia KY, Cretney E, Kelly JM, Snook MB, Forbes CA, et al. Perforin is a major contributor to NK cell control of tumor metastasis. J Immunol (1999) 162(11):6658-62.

17. Van den Broek MF, Kägi D, Zinkernagel RM, Hengartner H. Perforin dependence of natural killer cell-mediated tumor control in vivo. Eur J Immunol (1995) 25(12):3514-6. doi:10.1002/eji.1830251246

18. Johnsen AC, Haux J, Steinkjer B, Nonstad U, Egeberg K, Sundan A, et al. Regulation of APO-2 ligand/trail expression in NK cells-involvement in NK cellmediated cytotoxicity. Cytokine (1999) 11(9):664-72. doi:10.1006/cyto.1999. 0489
19. Lee RK, Spielman J, Zhao DY, Olsen KJ, Podack ER. Perforin, Fas ligand, and tumor necrosis factor are the major cytotoxic molecules used by lymphokineactivated killer cells. J Immunol (1996) 157(5):1919-25.

20. Zamai L, Ahmad M, Bennett IM, Azzoni L, Alnemri ES, Perussia B. Natural killer (NK) cell-mediated cytotoxicity: differential use of TRAIL and Fas ligand by immature and mature primary human NK cells. J Exp Med (1998) 188(12):2375-80. doi:10.1084/jem.188.12.2375

21. Vivier E, Raulet DH, Moretta A, Caligiuri MA, Zitvogel L, Lanier LL, et al. Innate or adaptive immunity? The example of natural killer cells. Science (2011) 331(6013):44-9. doi:10.1126/science.1198687

22. Imai K, Matsuyama S, Miyake S, Suga K, Nakachi K. Natural cytotoxic activity of peripheral-blood lymphocytes and cancer incidence: an 11-year follow-up study of a general population. Lancet (2000) 356(9244):1795-9. doi:10.1016/ S0140-6736(00)03231-1

23. Coca S, Perez-Piqueras J, Martinez D, Colmenarejo A, Saez MA, Vallejo C, et al. The prognostic significance of intratumoral natural killer cells in patients with colorectal carcinoma. Cancer (1997) 79(12):2320-8. doi:10.1002/(SICI)10970142(19970615)79:12<2320::AID-CNCR5>3.0.CO;2-P

24. Villegas FR, Coca S, Villarrubia VG, Jiménez R, Chillón MJ, Jareño J, et al. Prognostic significance of tumor infiltrating natural killer cells subset CD57 in patients with squamous cell lung cancer. Lung Cancer (2002) 35(1):23-8. doi:10.1016/S0169-5002(01)00292-6

25. Warren RP, Stembridge AM, Gardner EJ. Deficient immune function of peripheral blood mononuclear cells from patients with Gardner syndrome. Clin Exp Immunol (1985) 60(3):525-31.

26. Markowitz JF, Aiges HW, Cunningham-Rundles S, Kahn E, Teichberg S, Fisher SE, et al. Cancer family syndrome: marker studies. Gastroenterology (1986) 91(3):581-9.

27. Jović $\mathrm{V}$, Konjević G, Radulović S, Jelić S, Spuzić I. Impaired perforin-dependent NK cell cytotoxicity and proliferative activity of peripheral blood T cells is associated with metastatic melanoma. Tumori (2001) 87(5):324-9.

28. Menard C, Blay JY, Borg C, Michiels S, Ghiringhelli F, Robert C, et al. Natural killer cell IFN-gamma levels predict long-term survival with imatinib mesylate therapy in gastrointestinal stromal tumor-bearing patients. Cancer Res (2009) 69:3563-9. doi:10.1158/0008-5472.CAN-08-3807

29. Sconocchia G, Arriga R, Tornillo L, Terracciano L, Ferrone S, Spagnoli GC. Melanoma cells inhibit NK cell functions. Cancer Res (2012) 72(20):5428-9. doi:10.1158/0008-5472.CAN-12-1181

30. Halama N, Braun M, Kahlert C, Spille A, Quack C, Rahbari N, et al. Natural killer cells are scarce in colorectal carcinoma tissue despite high levels of chemokines and cytokines. Clin Cancer Res (2011) 17(4):678-89. doi:10.1158/1078-0432. CCR-10-2173

31. Balsamo M, Vermi W, Parodi M, Pietra G, Manzini C, Queirolo P, et al. Melanoma cells become resistant to NK-cell-mediated killing when exposed to NK-cell numbers compatible with NK-cell infiltration in the tumor. Eur J Immunol (2012) 42(7):1833-42. doi:10.1002/eji.201142179

32. Messaoudene M, Fregni G, Fourmentraux-Neves E, Chanal J, Maubec E, Mazouz-Dorval S, et al. Mature cytotoxic CD56(bright)/CD16(+) natural killer cells can infiltrate lymph nodes adjacent to metastatic melanoma. Cancer Res (2014) 74(1):81-92. doi:10.1158/0008-5472.CAN-13-1303

33. Erdag G, Schaefer JT, Smolkin ME, Deacon DH, Shea SM, Dengel LT, et al. Immunotype and immunohistologic characteristics of tumor-infiltrating immune cells are associated with clinical outcome in metastatic melanoma. Cancer Res (2012) 72(5):1070-80. doi:10.1158/0008-5472.CAN-11-3218

34. Sconocchia G, Spagnoli GC, Del Principe D, Ferrone S, Anselmi M, Wongsena $\mathrm{W}$, et al. Defective infiltration of natural killer cells in MICA/B-positive renal cell carcinoma involves beta(2)-integrin-mediated interaction. Neoplasia (2009) 11(7):662-71. doi:10.1593/neo.09296

35. Mamessier E, Sylvain A, Thibult ML, Houvenaeghel G, Jacquemier J, Castellano $\mathrm{R}$, et al. Human breast cancer cells enhance self tolerance by promoting evasion from NK cell antitumor immunity. J Clin Invest (2011) 121(9):3609-22. doi:10.1172/JCI45816

36. McKay K, Moore PC, Smoller BR, Hiatt KM. Association between natural killer cells and regression in melanocytic lesions. Hum Pathol (2011) 42:1960-4. doi:10.1016/j.humpath.2011.02.019

37. Ishigami S, Natsugoe S, Tokuda K, Nakajo A, Che X, Iwashige H, et al. Prognostic value of intratumoral natural killer cells in gastric carcinoma. Cancer (2000) 88(3):577-83. doi:10.1002/(SICI) 1097-0142(20000201)88:3<577::AIDCNCR13>3.0.CO;2-V 
38. Platonova S, Cherfils-Vicini J, Damotte D, Crozet L, Vieillard V, Validire $\mathrm{P}$, et al. Profound coordinated alterations of intratumoral NK cell phenotype and function in lung carcinoma. Cancer Res (2011) 71(16):5412-22. doi:10.1158/0008-5472.CAN-10-4179

39. Tomasello E, Yessaad N, Gregoire E, Hudspeth K, Luci C, Mavilio D, et al. Mapping of NKp46(+) cells in healthy human lymphoid and non-lymphoid tissues. Front Immunol (2012) 3:344. doi:10.3389/fimmu.2012.00344

40. Accomando WP, Wiencke JK, Houseman EA, Butler RA, Zheng S, Nelson HH, et al. Decreased NK cells in patients with head and neck cancer determined in archival DNA. Clin Cancer Res (2012) 18(22):6147-54. doi:10.1158/1078-0432. CCR-12-1008

41. Rocca YS, Roberti MP, Arriaga JM, Amat M, Bruno L, Pampena MB, et al. Altered phenotype in peripheral blood and tumor-associated NK cells from colorectal cancer patients. Innate Immun (2013) 19(1):76-85. doi:10.1177/ 1753425912453187

42. Roberti MP, Rocca YS, Amat M, Pampena MB, Loza J, Coló F, et al. IL-2- or IL-15-activated NK cells enhance Cetuximab-mediated activity against triplenegative breast cancer in xenografts and in breast cancer patients. Breast Cancer Res Treat (2012) 136(3):659-71. doi:10.1007/s10549-012-2287-y

43. Albertsson PA, Basse PH, Hokland M, Goldfarb RH, Nagelkerke JF, Nannmark $\mathrm{U}$, et al. NK cells and the tumour microenvironment: implications for NKcell function and anti-tumour activity. Trends Immunol (2003) 24(11):603-9. doi:10.1016/j.it.2003.09.007

44. Malmberg KJ, Bryceson YT, Carlsten M, Andersson S, Björklund A, Björkström NK, et al. NK cell-mediated targeting of human cancer and possibilities for new means of immunotherapy. Cancer Immunol Immunother (2008) 57(10):1541-52. doi:10.1007/s00262-008-0492-7

45. Sutlu T, Alici E. Natural killer cell-based immunotherapy in cancer: current insights and future prospects. J Intern Med (2009) 266(2):154-81. doi:10.1111/ j.1365-2796.2009.02121.x

46. Zamai L, Ponti C, Mirandola P, Gobbi G, Papa S, Galeotti L, et al. NK cells and cancer. J Immunol (2007) 178(7):4011-6. doi:10.4049/jimmunol.178.7.4011

47. Robbins SH, Bessou G, Cornillon A, Zucchini N, Rupp B, Ruzsics Z, et al. Natural killer cells promote early CD8 T cell responses against cytomegalovirus. PLoS Pathog (2007) 3(8):e123. doi:10.1371/journal.ppat.0030123

48. Krebs P, Barnes MJ, Lampe K, Whitley K, Bahjat KS, Beutler B, et al. NK-cellmediated killing of target cells triggers robust antigen-specific T-cell-mediated and humoral responses. Blood (2009) 113(26):6593-602. doi:10.1182/blood2009-01-201467

49. Kalinski P, Giermasz A, Nakamura Y, Basse P, Storkus WJ, Kirkwood JM, et al. Helper role of NK cells during the induction of anticancer responses by dendritic cells. Mol Immunol (2005) 42(4):535-9. doi:10.1016/j.molimm.2004.07.038

50. Gerosa F, Baldani-Guerra B, Nisii C, Marchesini V, Carra G, Trinchieri G. Reciprocal activating interaction between natural killer cells and dendritic cells. J Exp Med (2002) 195(3):327-33. doi:10.1084/jem.20010938

51. Amakata Y, Fujiyama Y, Andoh A, Hodohara K, Bamba T. Mechanism of NK cell activation induced by coculture with dendritic cells derived from peripheral blood monocytes. Clin Exp Immunol (2001) 124(2):214-22. doi:10.1046/j. 1365-2249.2001.01550.x

52. Della Chiesa M, Romagnani C, Thiel A, Moretta L, Moretta A. Multidirectional interactions are bridging human $\mathrm{NK}$ cells with plasmacytoid and monocyte-derived dendritic cells during innate immune responses. Blood (2006) 108(12):3851-8. doi:10.1182/blood-2006-02-004028

53. Ferlazzo G, Pack M, Thomas D, Paludan C, Schmid D, Strowig T, et al. Distinct roles of IL-12 and IL-15 in human natural killer cell activation by dendritic cells from secondary lymphoid organs. Proc Natl Acad Sci U S A (2004) 101(47):16606-11. doi:10.1073/pnas.0407522101

54. Martín-Fontecha A, Thomsen LL, Brett S, Gerard C, Lipp M, Lanzavecchia A et al. Induced recruitment of NK cells to lymph nodes provides IFN-gamma for $\mathrm{T}(\mathrm{H}) 1$ priming. Nat Immunol (2004) 5(12):1260-5. doi:10.1038/ni1138

55. Moretta A, Marcenaro E, Sivori S, Della Chiesa M, Vitale M, Moretta L. Early liaisons between cells of the innate immune system in inflamed peripheral tissues. Trends Immunol (2005) 26(12):668-75. doi:10.1016/j.it.2005. 09.008

56. Fernandez NC, Lozier A, Flament C, Ricciardi-Castagnoli P, Bellet D, Suter M, et al. Dendritic cells directly trigger NK cell functions: cross-talk relevant in innate anti-tumor immune responses in vivo. Nat Med (1999) 5(4):405-11. doi: $10.1038 / 7403$
57. Piccioli D, Sbrana S, Melandri E, Valiante NM. Contact-dependent stimulation and inhibition of dendritic cells by natural killer cells. J Exp Med (2002) 195(3):335-41. doi:10.1084/jem.20010934

58. Ferlazzo G, Tsang ML, Moretta L, Melioli G, Steinman RM, Münz C. Human dendritic cells activate resting natural killer (NK) cells and are recognized via the NKp30 receptor by activated NK cells. J Exp Med (2002) 195(3):343-51. doi:10.1084/jem.20011149

59. Moretta A. Natural killer cells and dendritic cells: rendezvous in abused tissues. Nat Rev Immunol (2002) 2(12):957-64. doi:10.1038/nri956

60. Morandi B, Mortara L, Chiossone L, Accolla RS, Mingari MC, Moretta L, et al. Dendritic cell editing by activated natural killer cells results in a more protective cancer-specific immune response. PLoS One (2012) 7(6):e39170. doi:10.1371/journal.pone.0039170

61. Bouwer AL, Saunderson SC, Caldwell FJ, Damani TT, Pelham SJ, Dunn AC, et al. NK cells are required for dendritic cell-based immunotherapy at the time of tumor challenge. J Immunol (2014) 192(5):2514-21. doi:10.4049/jimmunol. 1202797

62. Melero I, Rouzaut A, Motz GT, Coukos G. T-cell and NK-cell infiltration into solid tumors: a key limiting factor for efficacious cancer immunotherapy. Cancer Discov (2014) 4(5):522-6. doi:10.1158/2159-8290.CD-13-0985

63. Sun JC, Beilke JN, Lanier LL. Adaptive immune features of natural killer cells. Nature (2009) 457(7229):557-61. doi:10.1038/nature07665

64. O’Leary JG, Goodarzi M, Drayton DL, von Andrian UH. T cell- and B cellindependent adaptive immunity mediated by natural killer cells. Nat Immunol (2006) 7(5):507-16. doi:10.1038/ni1332

65. Paust S, Gill HS, Wang BZ, Flynn MP, Moseman EA, Senman B, et al. Critical role for the chemokine receptor CXCR6 in NK cell-mediated antigenspecific memory of haptens and viruses. Nat Immunol (2010) 11(12):1127-35. doi:10.1038/ni.1953

66. Cooper MA, Elliott JM, Keyel PA, Yang L, Carrero JA, Yokoyama WM. Cytokineinduced memory-like natural killer cells. Proc Natl Acad Sci U S A (2009) 106(6):1915-9. doi:10.1073/pnas.0813192106

67. Horowitz A, Behrens RH, Okell L, Fooks AR, Riley EM. NK cells as effectors of acquired immune responses: effector CD4+ T cell-dependent activation of NK cells following vaccination. J Immunol (2010) 185(5):2808-18. doi:10.4049/jimmunol.1000844

68. Gumá M, Angulo A, Vilches C, Gómez-Lozano N, Malats N, López-Botet M. Imprint of human cytomegalovirus infection on the NK cell receptor repertoire. Blood (2004) 104(12):3664-71. doi:10.1182/blood-2004-05-2058

69. Lopez-Vergès S, Milush JM, Schwartz BS, Pando MJ, Jarjoura J, York VA, et al. Expansion of a unique $\mathrm{CD} 57^{+} \mathrm{NKG} 2 \mathrm{Chi}$ natural killer cell subset during acute human cytomegalovirus infection. Proc Natl Acad Sci U S A (2011) 108(36):14725-32. doi:10.1073/pnas.1110900108

70. Mellman I, Coukos G, Dranoff G. Cancer immunotherapy comes of age. Nature (2011) 480(7378):480-9. doi:10.1038/nature10673

71. Cooper MA, Fehniger TA, Turner SC, Chen KS, Ghaheri BA, Ghayur T, et al. Human natural killer cells: a unique innate immunoregulatory role for the CD56bright subset. Blood (2001) 97(10):3146-51. doi:10.1182/blood.V97.10. 3146

72. Mazzolini G, Alfaro C, Sangro B, Feijoó E, Ruiz J, Benito A, et al. Intratumoral injection of dendritic cells engineered to secrete interleukin- 12 by recombinant adenovirus in patients with metastatic gastrointestinal carcinomas. J Clin Oncol (2005) 23(5):999-1010. doi:10.1200/JCO.2005.00.463

73. Osada T, Clay T, Hobeika A, Lyerly HK, Morse MA. NK cell activation by dendritic cell vaccine: a mechanism of action for clinical activity. Cancer Immunol Immunother (2006) 55(9):1122-31. doi:10.1007/s00262-005-0089-3

74. Di Nicola M, Zappasodi R, Carlo-Stella C, Mortarini R, Pupa SM, Magni M, et al. Vaccination with autologous tumor-loaded dendritic cells induces clinical and immunologic responses in indolent B-cell lymphoma patients with relapsed and measurable disease: a pilot study. Blood (2009) 113(1):18-27. doi:10.1182/blood-2008-06-165654

75. Van Tendeloo VF, Van de Velde A, Van Driessche A, Cools N, Anguille S, Ladell K, et al. Induction of complete and molecular remissions in acute myeloid leukemia by Wilms' tumor 1 antigen-targeted dendritic cell vaccination. Proc Natl Acad Sci U S A (2010) 107(31):13824-9. doi:10.1073/pnas.1008051107

76. Alfaro C, Perez-Gracia JL, Suarez N, Rodriguez J, Fernandez de Sanmamed M, Sangro B, et al. Pilot clinical trial of type 1 dendritic cells loaded with autologous tumor lysates combined with GM-CSF, pegylated IFN, and cyclophosphamide 
for metastatic cancer patients. J Immunol (2011) 187(11):6130-42. doi:10.4049/ jimmunol.1102209

77. Baek S, Kim CS, Kim SB, Kim YM, Kwon SW, Kim Y, et al. Combination therapy of renal cell carcinoma or breast cancer patients with dendritic cell vaccine and IL-2: results from a phase I/II trial. J Transl Med (2011) 9:178. doi:10.1186/1479-5876-9-178

78. Qi CJ, Ning YL, Han YS, Min HY, Ye H, Zhu YL, et al. Autologous dendritic cell vaccine for estrogen receptor (ER)/progestin receptor (PR) doublenegative breast cancer. Cancer Immunol Immunother (2012) 61(9):1415-24. doi:10.1007/s00262-011-1192-2

79. Pellegatta S, Eoli M, Frigerio S, Antozzi C, Bruzzone MG, Cantini G, et al. The natural killer cell response and tumor debulking are associated with prolonged survival in recurrent glioblastoma patients receiving dendritic cells loaded with autologous tumor lysates. Oncoimmunology (2013) 2(3):e23401. doi:10.4161/onci.23401

80. Pampena MB, Levy EM, Blanco PA, Barrio MM, Mordoh J. Immunomonitoring in a phase II/III trial of therapeutic vaccination with CSF-470 plus BCG plus GM-CSF versus IFN alfa in patients with cutaneous melanoma. Program and Proceedings of the AACR Special Conference on Tumor Immunology. Orlando, FL: American Association of Cancer Research (2014). Abstract 50.

81. Beano A, Signorino E, Evangelista A, Brusa D, Mistrangelo M, Polimeni MA, et al. Correlation between NK function and response to trastuzumab in metastatic breast cancer patients. J Transl Med (2008) 6:25. doi:10.1186/1479-5876-6-25

82. Voskens CJ, Watanabe R, Rollins S, Campana D, Hasumi K, Mann DL. Ex-vivo expanded human NK cells express activating receptors that mediate cytotox- icity of allogeneic and autologous cancer cell lines by direct recognition and antibody directed cellular cytotoxicity. J Exp Clin Cancer Res (2010) 29:134. doi:10.1186/1756-9966-29-134

83. Lee SC, Srivastava RM, López-Albaitero A, Ferrone S, Ferris RL. Natural killer (NK): dendritic cell (DC) cross talk induced by therapeutic monoclonal antibody triggers tumor antigen-specific T cell immunity. Immunol Res (2011) 50(23):248-54. doi:10.1007/s12026-011-8231-0

Conflict of Interest Statement: The authors declare that the research was conducted in the absence of any commercial or financial relationships that could be construed as a potential conflict of interest.

Received: 25 November 2014; accepted: 08 January 2015; published online: 28 January 2015.

Citation: Pampena MB and Levy EM (2015) Natural killer cells as helper cells in dendritic cell cancer vaccines. Front. Immunol. 6:13. doi: 10.3389/fimmu.2015.00013 This article was submitted to Immunotherapies and Vaccines, a section of the journal Frontiers in Immunology.

Copyright (c) 2015 Pampena and Levy. This is an open-access article distributed under the terms of the Creative Commons Attribution License (CC BY). The use, distribution or reproduction in other forums is permitted, provided the original author (s) or licensor are credited and that the original publication in this journal is cited, in accordance with accepted academic practice. No use, distribution or reproduction is permitted which does not comply with these terms. 